\title{
Empowerment of Posyandu Cadres in Assisting Infant Massage at Fatululi Pustu, Kupang City
}

\author{
Mariana Ngundju Awang, Yurissetiowati, Melinda R. Wariyaka \\ Kupang Ministry of Health Poltekkes \\ (ramyakeyken@gmail.com
}

\begin{abstract}
One form of growth and development stimulation that has been carried out by the community is by doing baby massage. Baby massage has many advantages, including reducing the habit of crying, gaining weight, making it easier for babies to sleep, practicing eye contact with the mother, reducing the baby's hormone stress level. The purpose of community service activities is to increase knowledge and skills of baby massage practice for Posyandu cadres and increase baby's weight and sleep quality. Materials used; phantom, questionnaire and internet quota.The methods are Pretest, Giving Materials through Lectures, Discussion/Question, Video screening and Posttest Followed by demonstrations, redemonstrations and direct massage practice on babies to improve Baby Massage Practice Skills. Results: Knowledge of baby massage before and after being given material with an assessment using the same instrument resulted in an increase in knowledge from a value of 50 to an average value of 80 values (minimum 70, maximum 90). Baby massage practice skills also increase along with the increase in knowledge so that it has an impact on weight gain and better sleep quality in babies. Conclusion; There is an increase in knowledge of cadres about infant massage followed by an increase in skills in terms of baby massage practices and the direct impact experienced by babies, namely increased weight gain and better sleep quality after being massaged every day regularly for 2 weeks.
\end{abstract}

Keywords: Baby massage, cadre empowerment Posyandu, kupang city

\begin{abstract}
One form of growth and development stimulation that has been carried out by the community is by doing baby massage. Infant massage has many benefits, including reducing the habit of crying, gaining weight, making babies sleep easily, practicing eye contact with mothers, reducing stress levels of baby hormones. The purpose of community service activities is to increase knowledge and practice skills of baby massage for Posyandu cadres and increase body weight and quality of baby sleep. Materials used; phantom, questionnaire and internet quota. Methods are pretest, giving material through lectures, discussion / question and answer, video screenings and posttests, followed by demonstrations, redemonstrations and direct massage practice to babies to improve Infant Massage Practice Skills. Results: Knowledge about infant massage before and after being given material with an assessment using the same instrument. The result was an increase in knowledge from a score of 50 to an average score of 80 (minimum 70, maximum 90). Practical skills of baby massage also improve along with the increase in knowledge so that it has an impact on weight gain and better sleep quality in babies. Conclusion; There is an increase in cadres' knowledge about infant massage followed by increased skills in terms of infant massage practices and the direct impact experienced by babies, namely increased weight gain and better sleep quality after being massaged every day regularly for 2 weeks. Practical skills of baby massage also improve along with the increase in knowledge so that it has an impact on weight gain and better sleep quality in babies. Conclusion; There is an increase in cadres' knowledge about infant massage followed by increased skills in terms of infant massage practices and the direct impact experienced by babies, namely increased weight gain and better sleep quality after being massaged every day regularly for 2 weeks. Practical skills of baby massage also improve along with the increase in knowledge so that it has an impact on weight gain and better sleep quality in babies. Conclusion; There is an increase in cadres' knowledge about infant massage followed by increased skills in terms of infant massage practices and the direct impact experienced by babies, namely increased weight gain and better sleep quality after being massaged every day regularly for 2 weeks.
\end{abstract}

Keywords: Infant massage, empowerment of Posyandu cadres, Kupang city 


\section{INTRODUCTION}

The Decree of the Minister of Health of the Republic of Indonesia Number 320/2020 concerning Midwifery Professional Standards states that midwives have the authority to carry out monitoring and stimulate the growth and development of infants and children. One form of growth and development stimulation that has been carried out by the community is by doing baby massage.Baby massage is a massage that is done to babies, toddlers using certain techniques to get maximum results(Minister of Health RI, 2020) Baby massage has many advantages, including reducing crying habits, gaining weight, making it easier for babies to sleep, practicing eye contact with mothers, reducing baby's hormone stress levels, also helping babies to defecate. (Idward, 2012).

The purpose of this activity is to socialize and teach baby massage skills to posyandu cadres and can pass these skills on to mothers of babies/toddlers which in turn can improve baby's health with indicators of weight gain and improved sleep quality in infants.

Proper baby massage has useful benefits for babies based on research conducted by Field and Schanberg (1986 \& 1990) showing that 20 premature babies (weight 1,289 and 1,176 grams) who were massaged 3 times 15 minutes for 10 days, experienced weight gain. body per day 20 percent 47 percent more than those who are not massaged. Research on term infants aged 1-3 months, who were massaged 15 minutes, 2 times a week for 6 weeks found weight gain was more than control. Babies who are massaged show an increase in vagus nerve tone (10th brain nerve) which will lead to increased levels of gastrin and insulin absorption enzymes, thus absorption of food will be better so that the baby's weight increases more than those who are not massaged.(Roesli Utami, 2013; Field et al., 2017)

Baby massage has many benefits so that the implementation of massage is very good if practiced, especially if the implementation is directly by the baby's father or mother. Besides the benefits, there are also disadvantages for babies who are not massaged, including babies who are not massaged, their weight gain is slower than babies who are massaged. Besides, usually babies who are massaged have a regular sleep pattern compared to babies who are massaged(Roesli Utami, 2013; Mariana ngundju awang, 2018), (Putro, 2019)

Baby massage has many advantages, including reducing crying habits, gaining weight, making it easier for babies to sleep, practicing eye contact with mothers, reducing baby's hormone stress levels, also helping babies to defecate.(Idward, 2012). This is in accordance with the results of research in Kupang in 2014 especially in LBW and Non LBW infants, that infant massage obtained optimal results seen from weight gain and sleep patterns, infants aged 0 - 3 months were massaged 15 minutes in the morning and evening before bathing. 100 percent gained weight gain with an average of $>200$ grams/week exceeding the normal limit of weight gain and an average sleep pattern of $>15 / 16$ hours/week. The results of the chi-square test of 0.02 means that there is a significant relationship between baby massage and weight gain and sleep patterns, also RR: 5.00 , so babies who are massaged every day have 5 times weight gain.(Mariana ngundju awang, 2018). In connection with the above, it is deemed important to teach about infant massage to posyandu cadres at the Fatululi Health Center to be able to directly apply the results of Risbinakes which are very useful, especially for infants with low birth weight,

\section{MATERIALS AND METHODS}

This type of community service is a partnership development program. The location of the activity is at Pustu Fatululi, Kupang City, East Nusa Tenggara Province. The implementation time of this activity is November 2020. The population of this activity is all cadres in the working area of the Fatululi Assistance Health Center which is located in 11 (Eleven Posyandu) a total of 55 people, a sample of 22 Cadres which is taken randomly 2 representatives from each Posyandu with criteria inclusion is an active cadre, Minimum working period of 2 years

The materials used in this activity are baby phantoms, questionnaires, internet quotas and babies. The team usesmethod of lectures, demonstrations and demonstrations to improve the skills of cadres in performing baby massage, then followed by mentoring cadres as a method to 
control the ability of cadres in carrying out their skills for direct massage of infants at the location of the activity.

\section{RESULTS}

At the beginning of the activity, participants took a pretest in the form of a questionnaire with closed questions to assess participants' knowledge about the definition, goals and benefits, uses, side effects, steps and indications and contraindications for the implementation of massage in infants before the baby massage training was carried out. Average knowledge of cadresabout the definition, purpose and benefits, uses, side effects, steps as well as indications and contraindications for the implementation of massage in infants before doing baby massage training an average of 60 (minimum value 50 and maximum 70 ).

Based on the results of the pretest, training activities were carried out starting with delivering baby massage material using the lecture method, discussion / question and answer, playing baby massage videos and demonstrations using Phantom Babies (due to the Pandemic period) so that they did not use human babies. After that, the community service team gave the Cadre the opportunity to redemove Baby massage using Phantom then distributed leaflets containing baby massage steps to be studied carefully before doing massage on babies directly.

After Submission of Materials and demonstration of Baby Massage Practices, the community service team conducted a posttest using the same assessment instrument as the instrument or questionnaire before the implementation of infant massage, the result was an increase in knowledge with an average score of 80 (minimum score 70 and maximum 90).

The practice of baby massage is considered competent based on redemonstration using phamton and continued with mentoring for 2 weeks. SBefore carrying out baby massage, first identify the number of healthy babies and there are no contraindications in the cadre's work area. After that, the cadres massage the babies in their respective homes monitored by the team and assisted by the Fatululi Health Center Midwife. Each cadre is divided into 1 baby to be given an intervention for baby massage. Babies are massaged by cadres for 2 weeks in a row with a frequency of 2 times/day (morning and evening before bathing).

Once competent individually Participants are divided per small group of 2-3 people and each cadre massages 1 baby and video is made, then sent to the Community Service Implementation Team for evaluation. Program evaluation is carried out periodically in accordance with the stages and progress of the realization of activities. The evaluation was carried out 3 times, namely the first stage of evaluation to determine the readiness of the cadres to perform massage on infants. Stage II evaluation was carried out after the mentoring period related to the ability of the cadres, the strengths and weaknesses of each cadre in applying massage to infants and stage III evaluation of the impact of baby massage, namely the increase in baby weight before and after the massage as well as sleep patterns.

The results of the assessment of participants' baby massage skills both through video and in person during mentoring are on average good. Even though based on observations there were some cadres who did not do 1-2 steps of baby massage correctly so it was necessary to repeat demonstrations to the cadres to remind the steps of baby massage and mentoring again until the person concerned was competent according to the steps of baby massage correctly. The positive thing that is obtained after this baby massage is that there is an increase in the knowledge and skills of Cadres andbabies who were massaged experienced an increase in body weight, improved sleep quality and comfort after baby massage by Cadres.

\section{DISCUSSION}

Knowledge of cadres prior to baby massage training. Based on the results of the pretest, it was found that the knowledge value of Cadres about baby massage was at least 50 , this was because the participants had never attended baby massage training while being cadres or before, because of this the cadres could not socialize baby massage. for posyandu participants who have babies and toddlers, so that mothers who have babies or toddlers have not provided baby massage stimulation to their children, this is with the results of(Oktobriani, 2010)Before 
health education was conducted about baby massage, most of the parents who had the ability to practice baby massage were less, namely 30 people (93.8\%). Only 2 people (6.3\%) have sufficient ability, and none at all has good ability.

Knowledge of cadres after Baby Massage. Based on the results of the Post test of Cadre Knowledge after being given the baby massage training material above, the maximum value of cadres is 90 . This shows that there is a significant increase in cadre knowledge from the Pre test after being given training using various media or methods ranging from lectures, questions/answers, videos, demonstrations, demonstrations and leaflets. This shows that the ease of information has an effect on increasing knowledge where the average increase in knowledge among students who receive balanced nutrition interventions with interventions using leaflets and lectures with slide media. The increase in students' knowledge with the lecture method with leaflet media is very significant, This is because participants are involved in the learning process by utilizing all the senses and using easy-to-understand media. The application of several methods in delivering material such as lectures, simulations and discussions can increase the knowledge of cadres(Bertalina, 2015), (Afrianti, 2014)

An increase in Cadre Knowledge in terms of baby massage has a direct impact on improving Cadre skills in carrying out baby massage practices directly according to the team's observations during mentoring, this is in accordance with what was said (Ratih Prananingrum, Ida Untari, 2017)that there is an increase in knowledge and skills of Posyandu cadres through the practice of baby massage, where knowledge in the good category is higher than knowledge before being given baby massage training, which is $32(88.9 \%)$ with the analysis test results showing the effect of training on knowledge with a $p$ value : 0.00 which means that there is a positive influence between the provision of infant massage training on the knowledge of cadres. Baby Massage Training given to health cadres is a science that will later be transferred to the community, especially families with toddlers, about how to detect health whether there are abnormalities in growth and development and correct baby massage.

The further impact of the increase in knowledge and skills of Posyandu cadres through the practice of baby massage is weight gain and improvement in the quality or pattern of infant sleep compared to before and after baby massage. This is possible due to an increase in the frequency of breastfeeding duration after massage(Farida, Mardianti and Komalasari, 2018). Baby massage that is done regularly with the right steps for at least 10-15 minutes can help increase weight. The results of Massage Practices from Cadres for 2 weeks during mentoring showed an increase of 200-300 grams/week in 22 babies who were massaged every day on a regular basis. This is in accordance with the results of massages for LBW and Non LBW babies that have been carried out at the PONED Health Center in Kupang(Mariana ngundju awang, 2018) (Harahap, 2019), (Kalsum et al., 2019), (Elvira and Azizah, 2017).Sleep quality also increases with weight gain, there is an increase in the duration of breastfeeding, this is in accordance with the results of the study (Ferius et al., 2016), (Month et al., 2014), (Kusumastuti, Tamtomo and Salimo, 2016; Mariana ngundju awang, 2018; Hartanti, Salimo and Widyaningsih, 2019)

\section{CONCLUSIONS AND SUGGESTIONS}

The implementation of Community Service Activities has been carried out well with the results of an increase in knowledge about cadres about infant massage followed by an increase in skills in terms of baby massage practices and a direct impact experienced by babies, namely increased weight gain and better sleep quality after massage. every day regularly for 2 weeks.

It is hoped that the Posyandu Cadres who have been trained can continue to practice baby massage so that they are more skilled and can teach mothers of infants and toddlers or prospective mothers and other Cadre friends. It is also hoped that there will be continuous monitoring of the midwives in their fostered areas of the massage practices of the cadres, evaluating or monitoring the growth and development of babies being massaged. 


\section{ACKNOWLEDGMENTS}

The author expresses his deepest gratitude to Poltekkes Kemenkes Kupang for providing support for the implementation of this community service activity. In addition, the authors also express gratitude to the Head of the Fatululi Pustu, doctors and midwives who work there as well as cadres who take part in community service activities with the title "Empowerment of Posyandu Cadres in Assisting Infant Massage at Fatululi Pustu, Kupang City".

\section{REFERENCES}

(Bertalina, 2015)The Effect of Health Promotion on Increasing Knowledge About Balanced Nutrition in State Elementary School Students in Rajabasa District, Bandar Lampung City. Department of Nutrition Poltekkes Ministry of Health Tanjungkarang. Journal of Health, Volume VI, Number 1, April 2015, pp. 56-63.

(Month et al., 2014) 'The Effects of Massage on the Quality of Sleeping in Babies 3-4 Months Old at Gelatik and Nuri IHCs of Tanjung Unggat Health Center', 1(3), pp. 144-150. doi: 10.26699/jnk.v1i3.ART.p230-235.

(Elvira and Azizah, 2017)'The Effect of Infant Massage on Weight Gain in Infants aged 0-6 Months at BPS Bunda Bukittinggi', Journal of Nagari Development, 2(1), p. 85. doi:10.30559/jpn.v2i1.16.

(Ferius et al., 2016)'The Effect of Infant Massage Using Mineral Oil or Coconut Oil on Weight Gain in Term Neonates', Sari Pediatri, 10(4), p. 219. doi:10.14238/sp10.4.2008.219-24.

(Field et al., 2017)Tactile/Kinesthetic Stimulation Effects on Preterm Neonates. Journal of the American Academy of Pediatrics, 77, 654-658. Retrieved February 20, 2020 fromhttp://www.pediatrics.org

(Harahap, 2019)'Baby Massage Increases Baby's Weight 0-6 Months', Prima Health Journal, 13(2), p. 99. doi:10.32807/jkp.v13i2.226.

(Hartanti, Salimo and Widyaningsih, 2019)'Effectiveness of Infant Massage on Strengthening Bonding and Improving Sleep Quality', Indonesian Journal of Medicine, 4(2), pp. 165-175. doi: 10.26911/theijmed.2019.04.02.10.

(Idward, 2012). Baby massage. Indonesian Ministry of Health, Directorate General of Nutrition and $\mathrm{MCH}$. (Online) Information available: http://www.gizikia.depkes.go.id/article/pijat-bayi/. Accessed February 27, 2020

(Kalsum et al., 2019)'EFFECT OF BABY MASSAGE TO INCREASE WEIGHT JETIS YOGYAKARTA Effect Of Baby Massage To Increase Weight And Baby Sleep Quality At Jetis Public Health Center Yogyakarta', 3(1), pp. 165-175. doi:10.26699/jnk.v1i1.ART.p052-056.

(Kusumastuti, Tamtomo and Salimo, 2016)'Effect of Massage on Sleep Quality and Motor Development in Infant Aged 3-6 Months', Journal of Maternal and Child Health, 01(03), pp. 161-169. doi:10.26911/thejmch.2016.01.03.03.

(Mariana ngundju awang, 2018)'1. The effect of baby massage using head oil on weight gain and sleep patterns of term, LBW and non-LBW infants aged 0-3 months at the PONED Public Health Center in Kupang', CHMK Midwifery Scientific Journal, 2(2), pp. 13-19. Available at:http://cyber-chmk.net/ojs/index.php/bidan/article/view/8.

(Minister of Health RI, 2020)Decree of the Minister of Health of the Republic of Indonesia Number Hk.01.07/Menkes/320/2020 concerning Midwife Professional Standards. Jakarta.

(Oktobriani, 2010). The Effect of Health Education on Infant Massage on the Practice of Infant Massage at the Harapan Polindes, Bunda Sukoharjo. Scientific papers. Midwifery DIV Study Program. Faculty of Medicine, Sebelas Maret University, Surakarta

(Putro, 2019)'Importance of the Benefits of Infant Massage in Infants Age 0-12 Months', Dinamisia: Journal of Community Service, 3, pp. 49-52. doi:10.31849/dinamisia.v3i2.2844

(Ratih Prananingrum, Ida Untari, 2017). Improving Knowledge and Skills of Toddler Posyandu Cadres Through Infant Massage Practices Towards Healthy Toddlers. The 6th University Research Colloquium. Muhammadiyah University of Magelang

(Roesli Utami, 2013)Baby Massage Guide. Jakarta: Trubus Agriwidya - Guidelines for Baby Massage. Jakarta: Trubus Agriwidya 


\section{ATTACHMENT}

Table 1

Score Results Before Giving Baby Massage Training Materials

\begin{tabular}{|c|c|c|}
\hline Average score before & Minimum & Maximum \\
\hline 60 & 50 & 70 \\
\hline \multicolumn{3}{|c|}{ Table 2} \\
\hline Average value after & Minimum & Maximum \\
\hline 80 & 70 & 90 \\
\hline
\end{tabular}

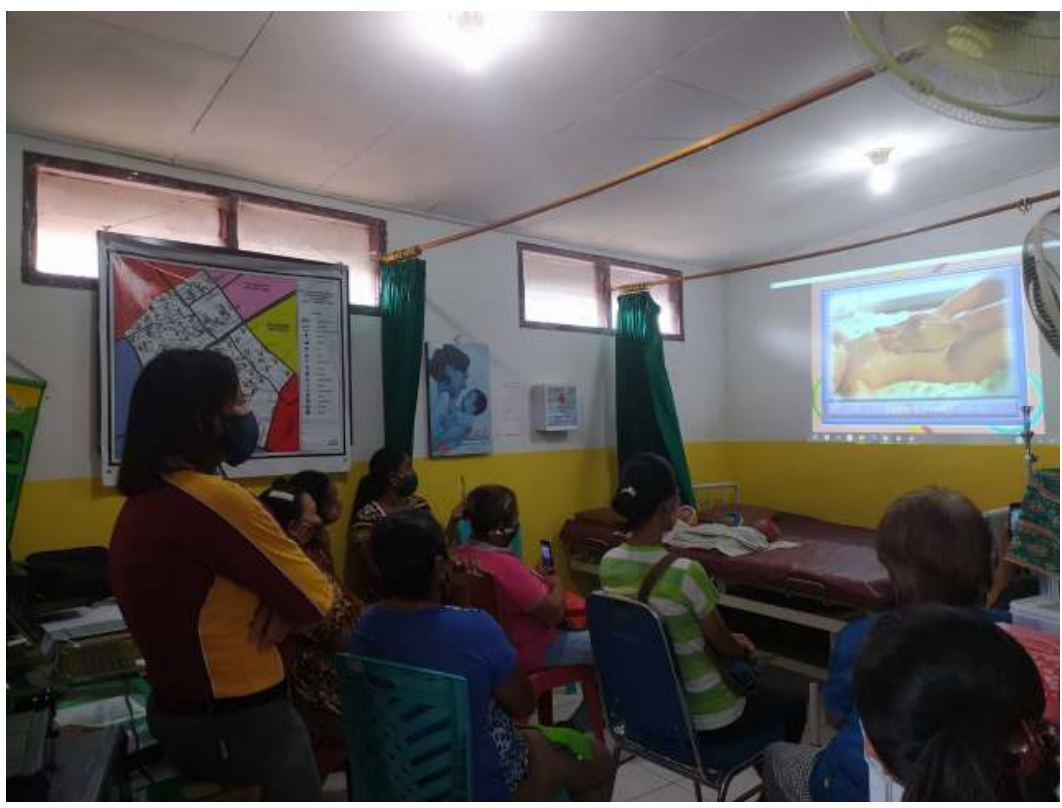

Figure 1. Baby Massage Video Playback

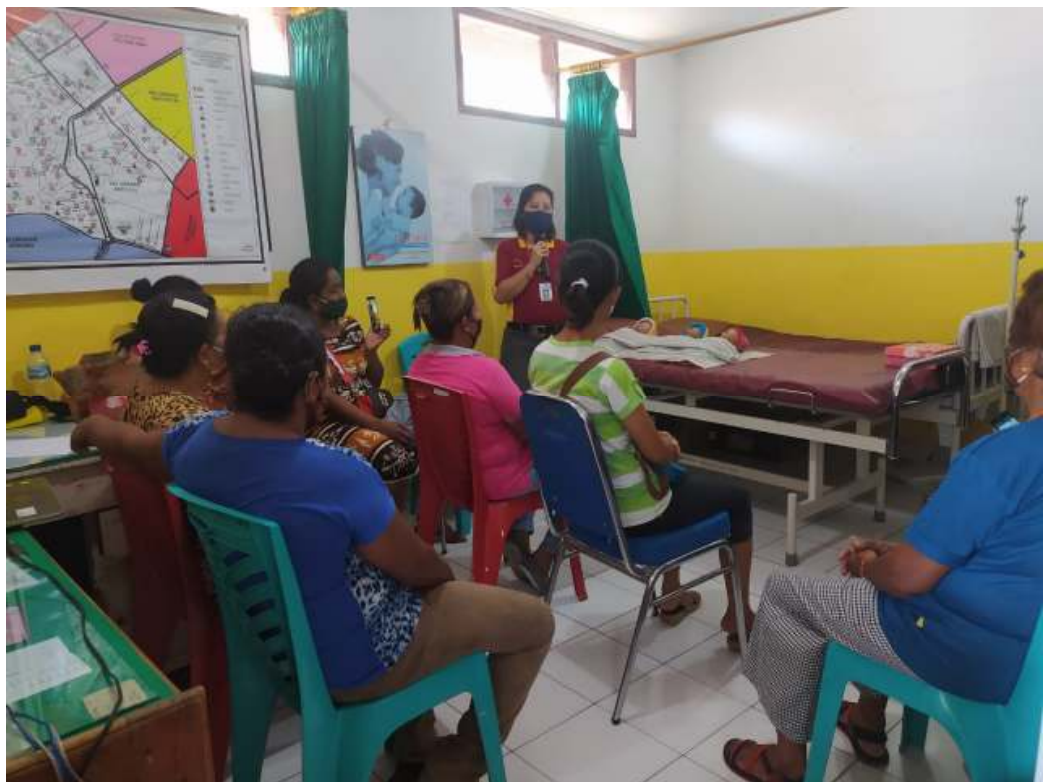

Figure 2. Delivery of Baby Massage Materials and discussions 


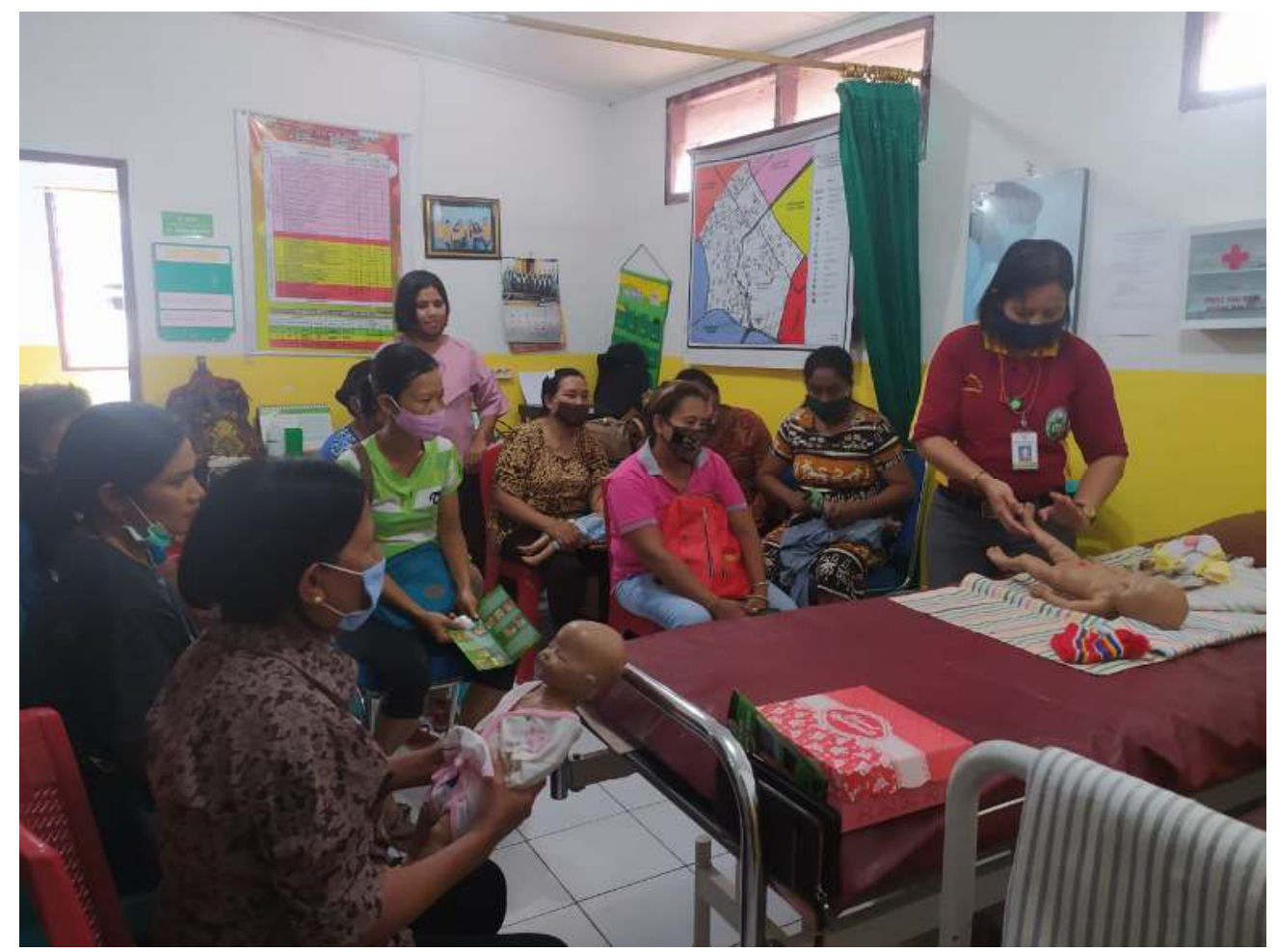

Figure 3. Demonstration of Baby Massage on Phantom

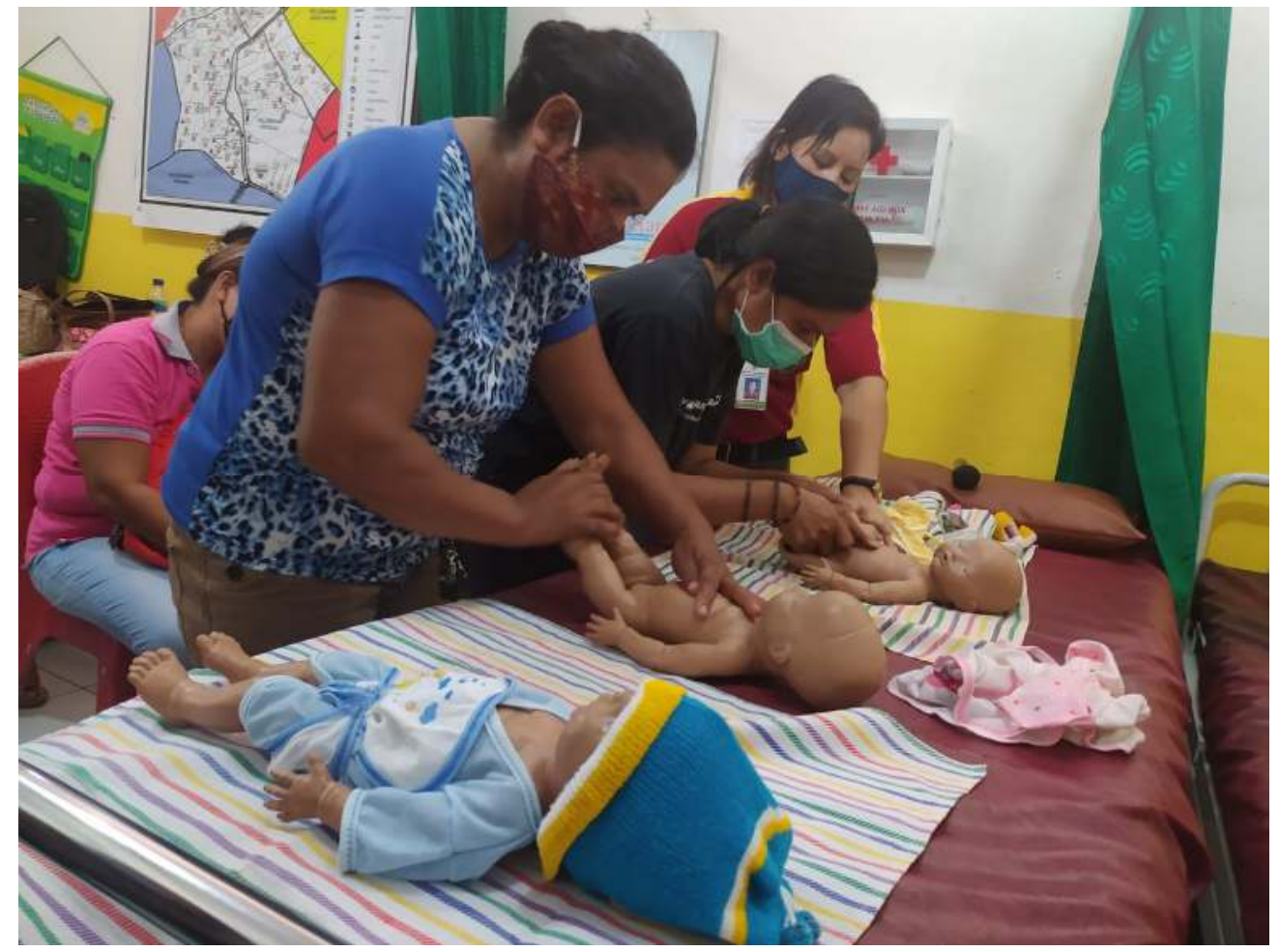

Figure 4. Redemonstration of Baby Massage with Guidance 


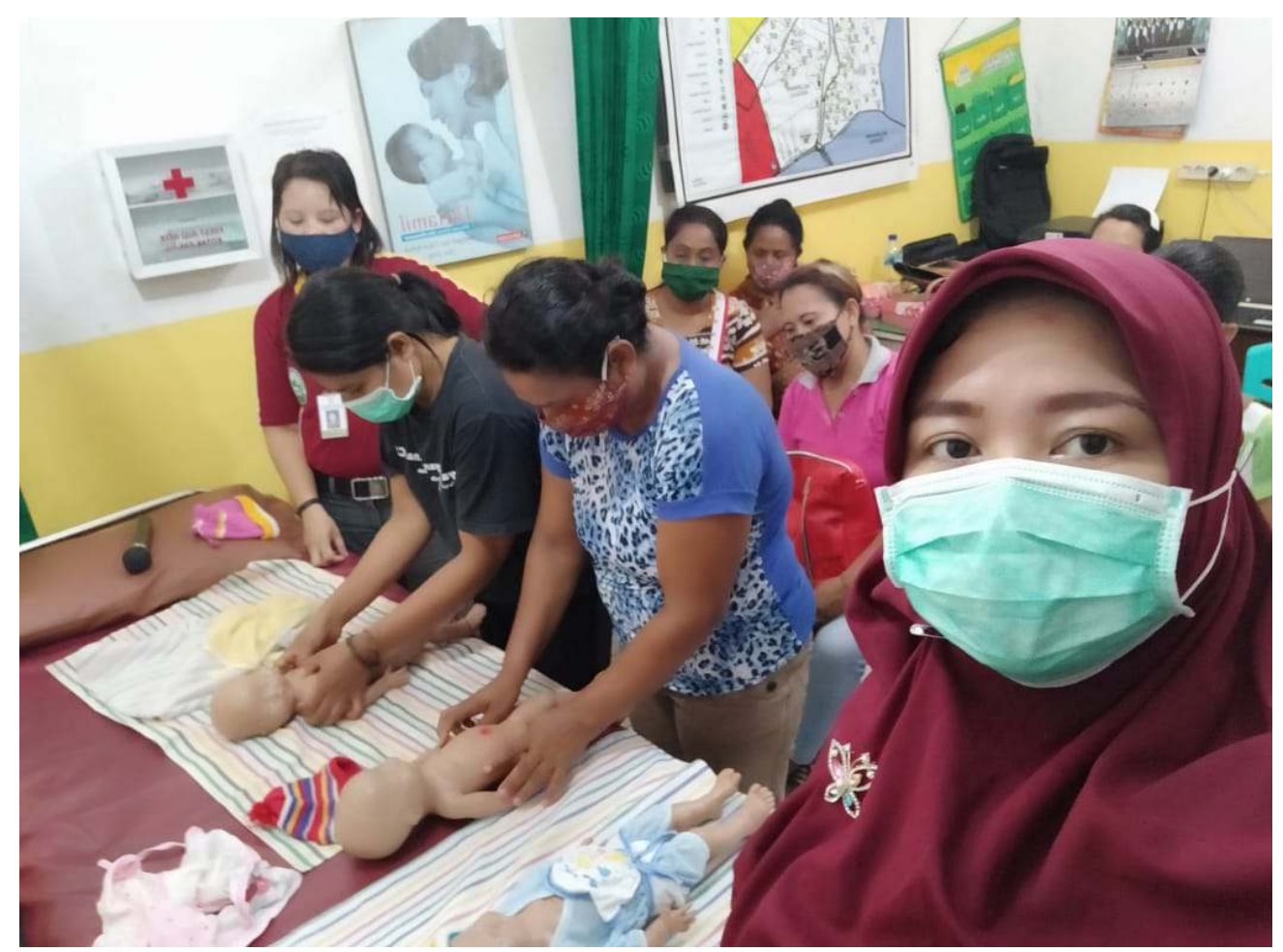

Figure 5. Redemonstration of Baby Massage with Guidance

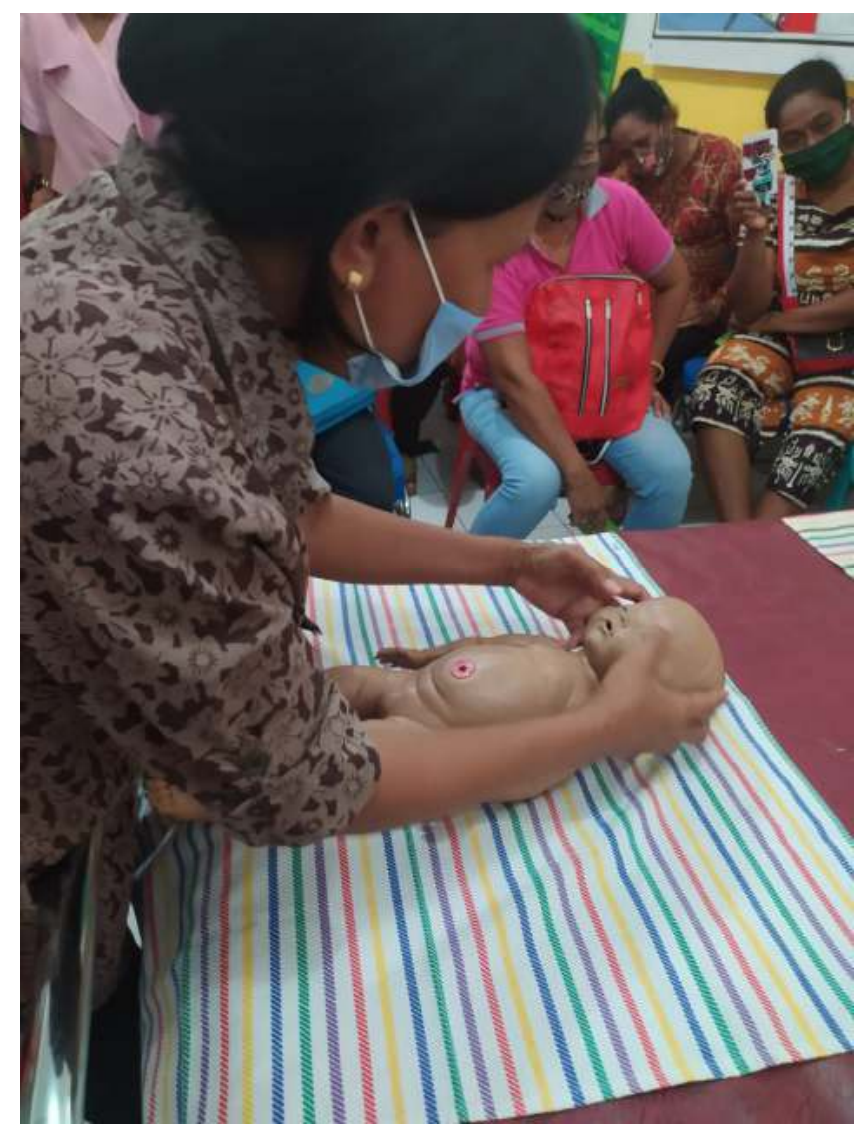

Figure 6. Self-Demonstration of Baby Massage 


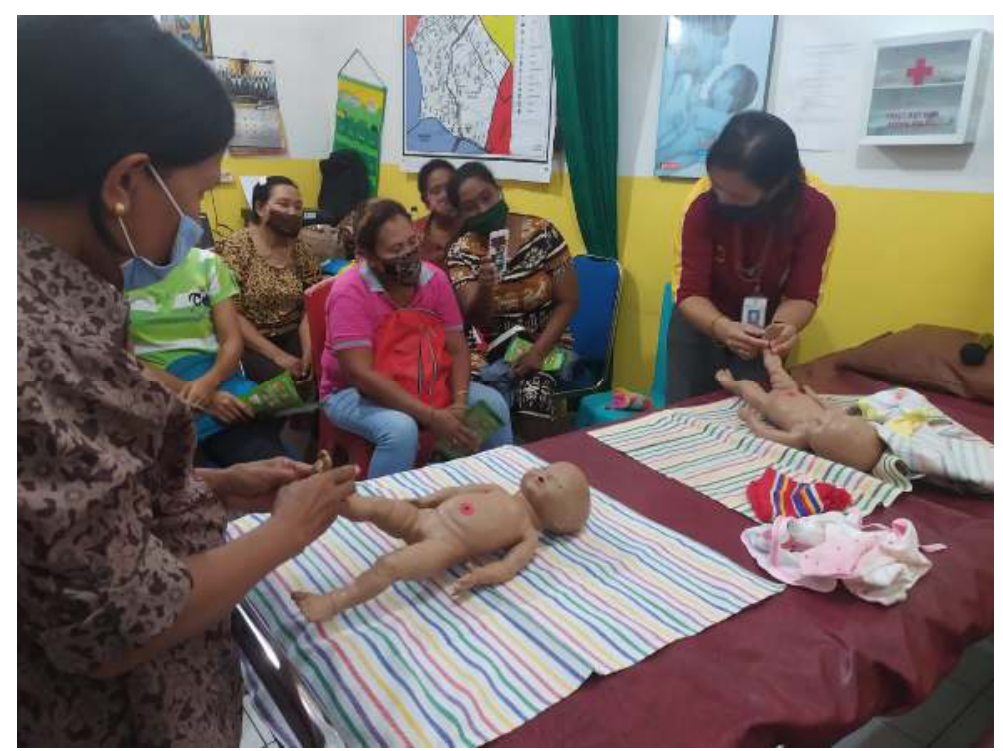

Figure 7. Activity Evaluation

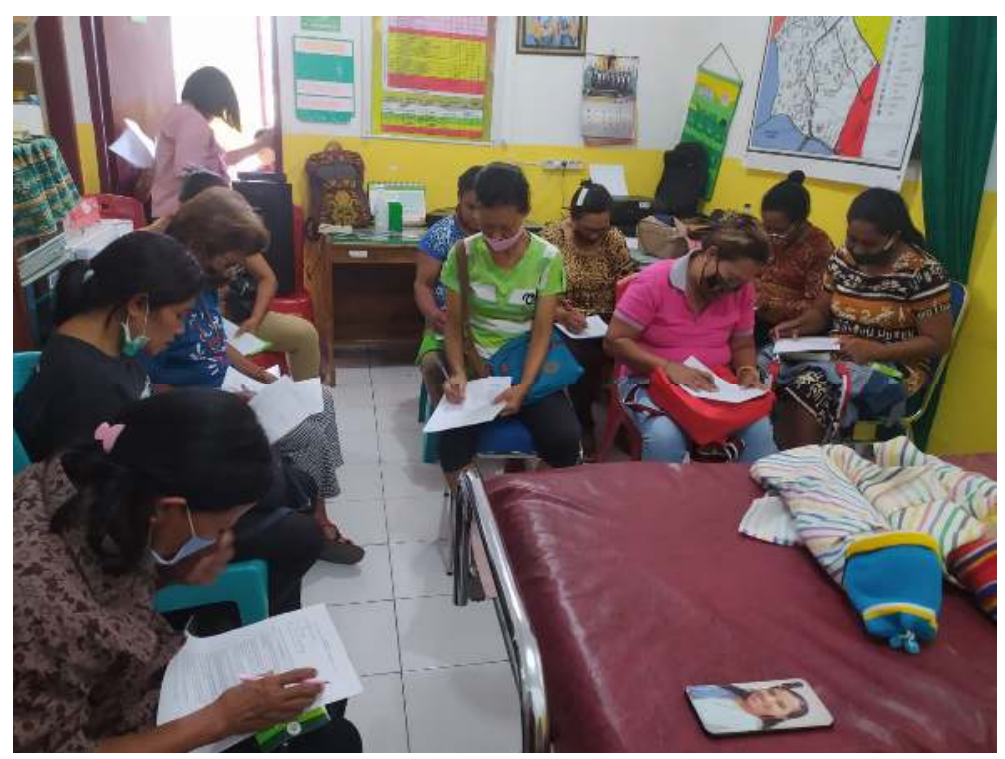

Figure 8. Filling in the Questionnaire

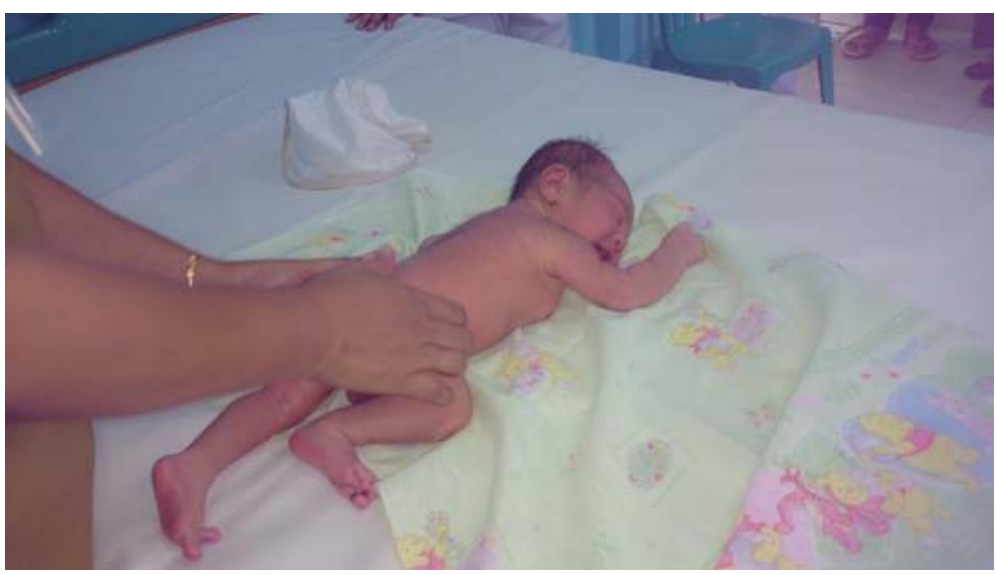

Figure 9. Massage practice on babies directly 